\title{
Research on the Market Access of Cold Chain Logistics Service Quality Safety for Agricultural Products
}

\author{
Xin'gang Weng, Jiuyi An, Yangyang Hu \\ Beijing Wuzi University, Beijing, China \\ Email: anjiuyi@126.com
}

Received 29 September 2015; accepted 16 November 2015; published 19 November 2015

Copyright $@ 2015$ by authors and Scientific Research Publishing Inc.

This work is licensed under the Creative Commons Attribution International License (CC BY). http://creativecommons.org/licenses/by/4.0/

cc) (i) Open Access

\begin{abstract}
The cold chain logistics service quality safety of agricultural means that cold chain logistics services must meet requirements relating to human health, safety and quality. It needs to be regulated by law, compulsory supervision and security, which mainly refers to the quality of service safety. From the connotation of the cold-chain logistics service quality safety of agricultural products market access analysis, this article cards the agricultural cold chain logistics service quality safety market access system components and puts forward the system frame of quality safety of agricultural products cold chain logistics service market access policy.
\end{abstract}

\section{Keywords}

Cold Chain Logistics of Agricultural Products, Service Quality, Safety Market Access

\section{Agricultural Products Cold Chain Logistics Service Quality Safety Market Access Connotation}

\subsection{The Connotation and Extension of Market Access}

Concept of market access first began in the 1930s. In 1929, the capitalist world's worst outbreak of the economic crisis declared bankruptcy of Adam Smith's "laissez-faire" market economy theory. People began to realize that relying solely on self-regulation of the market economy could not solve all the problems of their own. After the world economic crisis in 1933, the capitalist countries began to accept the Keynesian theory of national macro-regulation and the state began to implement economic oversight and regulation. At this time, the concept of market accessed and produced [1].

Market access is a foreign language by the introduction of new office vocabulary in Chinese. In the late 1980s, 
in the process of ready to join the General Agreement on Tariffs and Trade (GATT), our country began to introduce and translate relevant legal documents and research related systems of other countries, and introduced a reference to Market Access. Some scholars have put Access Market as “market access”. Since then, “market access" gradually became a general term, and it first appeared in the official legal documents in 1992, "the Chinese and American market access memorandum of understanding”. From the point of view of economics, market access refers to the main trading partners and the government permission to enter the market of the extent and scope. From a legal point of view, "market access” is referred to as abbreviation of the market access system, which refers to the state regulation of market players and trading partners to enter the market about the legal norms in general [2].

In order to maintain economic order, market access generally refers to the government (or country) according to the main elements of the market, goods, services and capital allowed into the country's economic situation to develop a country, region or field of legal norms of the market. It is based on the market fundamentals, the initial state intervention, government management market, and institutional arrangements for intervention in the economy. Market access generally refers to goods, services and capital into the market level of license. For the market access of products, the general understanding is the market's main body (the producer and seller of goods) and the object (product) to enter the market the degree of permission. Market access system can be divided into subject and object of quasi-quasi-human, namely producers and product access.

\subsection{The Connotation of the Quality Safety of Agricultural Products Cold Chain Logistics Services}

Agriculture Products Cold Chain is a special supply chain system. It includes the instigation of meat, poultry, aquatic products, vegetables, fruits, eggs and other fresh produce harvested (or slaughter, fishing) from the origin, the product processing, storage, transportation, distribution, retail and other sectors which has always been a suitable temperature controlled environment to ensure maximum product quality and quality safety, reduce losses, prevent pollution. Agriculture Products Cold Chain by agricultural producers (farmers/production base), agricultural procurement and processing enterprises, and agricultural distributors, retailers and logistics enterprises, "from farm to table" chain logistics service network downstream businesses composed of formula system. Specifically, Agriculture Products Cold Chain includes agricultural production, acquisition, sale of pre-cooling process, transportation, storage, handling, transportation, packaging, distribution, circulation processing, information activities and other sectors, and aims to achieve organizational goals and produce value added in the process.

Agricultural production referred by “People’s Republic of China Agricultural Product Quality Safety Law” means plants, animals, microorganisms and their products from primary agricultural products obtained in agricultural activities. The quality safety of agricultural products mentioned in the act refers to the quality of agricultural complying with health and safety requirements to protect people. Agricultural production cold chain logistics a special supply chain system. It is the guarantee of origin (or slaughter, fishing) where it was from, the product processing, storage, transportation, distribution, retail and other aspects of product quality and quality of meat, poultry, aquatic products, vegetables, fruits, eggs and other fresh. It requires producing security, reducing losses, and preventing pollution. So it is an important part to guarantee the quality safety of agricultural products, support quality of agricultural product and meet the protection of human health and safety requirements of important ancillary support system.

Generally speaking, agricultural products cold chain logistics service quality is the sum of the cold chain logistics activities in the process to meet the requirements specified or potential (or need) features and characteristics. Connotation of quality of service should include general safety requirements, suitability, effectiveness and economy service. Agriculture Products Cold Chain the quality of service and security is involved in cold chain logistics services to meet the health, quality safety requirements. The need should be regulated by law and compulsory supervision and security, mainly refers to the quality of service safety.

\subsection{The Connotation of the Cold-Chain Logistics Service Quality Safety of Agricultural Products Market Access}

In a narrow sense, the market is a place for buyers and sellers to exchange goods. Broadly, the market is a place to buy and sell goods or services associating with other vendors and individual vendors and individual cluster. 
Cold chain logistics service quality agricultural market access "market" in this research refers to agricultural products "from farm to table" the upstream and downstream enterprises engaged in pre-cooling, transportation, storage, handling, transportation during the production, acquisition and sale of agricultural products, packaging, distribution, circulation processing, information activities and other agricultural products cold chain logistics activities of businesses or individuals constitute a cluster.

Agricultural cold chain logistics service quality safety market access refers to the government to regulate agricultural cold chain logistics market order and protects the safety of consumer spending, through the necessary legal procedures to permit compliance with the safety standards of agricultural products cold chain logistics service quality of agricultural products into the market services regulatory actions and processes. From market access regulations at home and abroad to carry out, the agricultural products cold chain logistics service quality safety market access is by a qualified certification body or certification authorities (authorization) service principal, and tested quality safety indicators in line with agricultural Cold Chain logistics service quality standards mandatory safety services grant people business. For non-certified (recognized), detection (quarantine) or tested (quarantine) failed services, operators are not allowed to enter the market, prohibit or restrict its business scope. Organization of agricultural cold chain logistics service quality security market players are engaged in cold-chain logistics activities, business or personal, market various objects around fresh agricultural products cold chain logistics services provided.

\section{The Analysis of Agricultural Cold Chain Logistics Service Quality Safety Market Access System Components}

\subsection{The Analysis of Market Access Regulation Subject}

As a government regulation act, Agriculture Products Cold Chain Market Access Regulation fabricated produces cold chain logistics service quality safety market access relevant government departments in accordance with law on the activities of market players to regulate behavior. Agriculture Products Cold Chain body as agricultural production, marketing and consumption of links link agricultural products quality safety supervision and management of an important part. Agriculture Products Cold Chain body includes fresh produce transport operators of refrigerated transport business enterprises or individuals, companies or individuals operating cold storage of fresh agricultural products, as well as two or more operating businesses agricultural processing and distribution companies or individuals. "People's Republic of China Agricultural Product Quality Safety Law" cleared the people's governments above the county level administrative department of agriculture in charge of agricultural product quality safety supervision and management; people's governments above the county level in accordance with the division of responsibilities is responsible for the quality safety of agricultural related work. The law of "people's governments above the county level" includes health administration, agriculture administration, quality supervision, industry and commerce administration, food and drug supervision and management departments. "People’s Republic of China Agricultural Product Quality Safety Law" does not explicitly Agriculture Products Cold Chain relating to subjects of regulatory authorities. The State Council in the "on the strengthening of the circulation system of agricultural products fresh opinion" that only the Ministry of Commerce, Development and Reform Commission, the Ministry of Agriculture should work together with the Ministry of Finance, Ministry of Land, Housing and Urban Construction, Ministry of Transport, Railways, SAT, AQSIQ, China Banking Regulatory Commission, China Insurance Regulatory Commission, Supply and marketing cooperatives and other departments and units to strengthen supervision and guidance, the circulation system of study and solve major problems in fresh agricultural products. The "opinions" have no clear on agricultural products cold chain logistics service quality safety management of law enforcement body, as well as the division of responsibilities of various departments [3].

In accordance with the reality of cold chain logistics body regulate agricultural situation, major government regulatory departments, including: responsible for health and safety practitioners and facilities and equipment health management departments at all levels are responsible for the management of agricultural refrigerated transport traffic management department, security of Quality Supervision cold department, certification of industrial and commercial administration departments.

\subsection{Analysis of Market Access Regulation Objective}

Regulation of the object is called market access business subject or object of regulation. However, cold chain 
logistics services regulation has a certain degree of particularity. Its business entities provide can not exist apart from business entities. Agricultural products cold chain logistics services regulation object refers to a variety of organizations engaged in cold-chain logistics services in agricultural production and marketing process. Regulation in accordance with the principles of moderate and progressive advance from the object chain logistics services, due to the type of agricultural division multiplexing. We can not implement all of the main agricultural products cold chain logistics services regulation. Early regulation, the government should focus primarily on the people involved in everyday life, and have a significant impact on international trade, greater risk of cold chain logistics service principal agricultural implement access regulations. For the main access, we should give full play the role of intermediary organizations and industry self-regulation as a supplement to make up for lack of government regulation.

\subsection{Analysis of Range of Market Access}

Scope of agricultural products cold chain logistics market access includes management project and form. Management projects are approved in accordance with the category of agricultural products; Business form is according to the agricultural products in the process of production, purchasing and the acquisition of agricultural products, transportation, storage, loading and unloading, handling, packaging, distribution, circulation processing, information services and other business category for approval.

\subsection{Market Access Rules and Regulations}

Market access rules include laws, regulations, rules and other normative documents. It is used to establish market access order a series of political and legal system. China's current agricultural market access rules and cold-chain logistics system can be divided into the following three categories: First, the law, the highest national legislature promulgated the normative documents, such as "People's Republic of China Agricultural Product Quality Safety Law," "People's Republic of China administrative Licensing Law"; two is the administrative regulations, namely the State Council promulgated the normative documents, such as "waterway transport regulations", "international Maritime regulations"; Third, departmental regulations issued by the central ministries, such as the "packaging of agricultural products and identity management approach" and so on. In addition, there are local regulations and technical norms and standards.

\subsection{Market Access Control Means}

\subsubsection{Administrative Measures}

Administrative measures are currently the most used, such as licensing, pre-approval, approval and so on. Divided by purpose, administrative license categories include behavioral licensing and qualifications. Behavior refers license allows qualified applicants to engage in certain activities. Qualification means the administrative body permitted application of the applicant, after a certain assessment procedures issued proof of certain instruments, allowing it to enjoy a qualification or license has some ability, such as driving licenses and so on [4]. Licensing system is necessary and determine the eligibility of competitors, competition right, and into the range of competitors in specific areas and should have the preconditions to determine national protection or object opposition It has standardized guide significance and protects the competition and effective measures order.

\subsubsection{Legal Means}

Administrative means can not leave legal means. Government departments exercise administrative powers must be authorized by law as a precondition. It can only exercise the powers conferred by law, the Constitution, the highest legal standards, strict implementation of the administrative act in accordance with the law. Within the specified range, the administrative body should take the initiative to actively full and effective exercise of authority.

\subsubsection{Economic Instruments}

By taking government tax incentives, subsidies, price, antitrust and other means to encourage or restrict into some market players. Compared with the previous two, economic instruments means less mandatory to stimulate the main easier for market players to accept. But the effects of the current economic ping segment is inferior to the two straightforward and efficient, and the government's economic management capacity need to be higher. 


\section{Cold Chain Logistics of Agricultural Products Market Access Problem Analysis}

\subsection{Technical Standards Lag}

Accessing to the first line of mark is by the bureau of quality supervision, inspection, import and export inspection and quarantine bureau and other departments jointly guarded, by a series of quality and technical standard. But at present, a lot of agricultural products cold chain logistics service standards lag behind the development of the industry or international standard, making the control of production process having a lot of loopholes.

\subsection{The System's Weak}

Second access gateway mainly rely on the industry and Commerce Bureau in the field of supervision. Due to the lack of human and material resources and other factors, as well as the complex environment of China's population, it leads to the weak and weak access gateway. Although the government will implement the access system in the cold chain logistics field, the flow of enterprises in the implementation of the system of the "water" results in agricultural products cold chain logistics service security problems or continue to appear.

\subsection{The Lack of Legal Provisions and Gaps in Access}

At present, some large cities have implement the access system in the food supply of agricultural products cold chain logistics field, but the violation of the system or not to comply with the regulations of the system not related to the laws, regulations not punished, the lack of relevant fines, and the lack of these regulations lead to the implementation of the system becoming weak and inefficient.

\subsection{The Impact of Access to the Effect of the Third Party Agencies Did Not Play Its Due Role}

In foreign third party organizations, such as the association, testing agencies in the cold chain logistics market access has played a very good role, some of the association is the standard setting, access control, and a lot of large inspection agencies have international authority, in the domestic cold chain logistics service quality safety of the market plays a key role. But the domestic associations and testing organizations are in virtually all of the third party without the influence of the enterprise. Currently independent capacity, service awareness, authority are not established [5]. In addition, our country has no technical standards, inspection facilities and international standards, and a certain size, we recognized the testing organizations, which have led to the association in the current market access is difficult to take responsibility.

\subsection{Enterprise Self-Discipline and Consumers Are Still in the Embryonic Stage}

In foreign countries, there has formed a good faith and the legal system of the market environment, which also makes the enterprise on the one hand to fear the strict law. On the other hand, it is good for the long-term development of enterprises. The general form of a "self restraint" mechanism, enterprises can better provide qualified products for the community. At the same time, due to the developed market environment, cold chain logistics service quality is higher, and it has trained a number of consumers. These consumers also play a role in monitoring the quality of services. You can say that they have served as a market access, inspector”. It can be said that the enterprise's self-discipline and the consumer's self awakening constitute a benign market environment for foreign market access.

In contrast, in the domestic market, because the economy is not very developed, social credit is still very weak, and legal system is not perfect, the self-discipline of the majority of enterprises in the face of short-term economic benefits become vulnerable. At the same time, because of the lack of consumer protection mechanisms and measures, there has been despite complaints from a number of sources over the past few years. But due to the high cost of cumbersome procedures, inspection fees, consumers generally have no the energy, time, money to do battle with company. So the supervision of service consumers will become negligible. And a lack of integrity, corporate self-regulation and consumer self awakening market is also difficult for the government to control the quality of service related sectors [6]. Our country is a large floating population and the consumption level of the complex market environment, which will undoubtedly increase the difficulty of using market access to monitor.

In addition, the current regulatory information on the parties to communicate and share mechanism have not 
been formed, and there is no information on the formation of a network to condense the parties together, which also reduces the efficiency of market access.

\section{Agricultural Products Cold Chain Logistics Service Quality Safety Market Access Policy System Framework}

Agricultural products cold chain logistics service quality safety market access system should include market players or services into the market, service links, and market players or services delisting link.

\subsection{The Market Segment}

\subsubsection{The Agricultural Cold Chain Logistics Service Quality Safety Certification}

Agricultural products cold chain logistics service quality safety certification is the certification body according to national and industry relating standards and certification requirements. In the region of agricultural products cold chain logistics service management environment, service management technology, service quality and other aspects of scientific monitoring and on-site inspection, it confirmed that it is in conformity with relevant standards for agricultural products cold chain logistics enterprises or service projects to provide effective access basis for certification. It can be seen that the cold chain logistics service quality safety certification is an important part of the agricultural products cold chain logistics service quality safety market access regulation. Agricultural products cold chain logistics service quality safety certification from the function is divided into two kinds of compulsory certification and voluntary certification. Compulsory certification is for a class of services or enterprises and the use of mandatory standards, through the provisions of the procedures for the assessment of conformity. China has not yet established a mandatory certification system for agricultural products cold chain logistics service quality. Voluntary certification is the operator to create product brands. It also can improve service reputation through third party certification body to carry out certification, such as enterprise A certification. From the certification object, it is divided into service certification and system certification. The object of the service certification evaluation includes service environment, service process, service record and service quality. System authentication mainly focuses on the service process control, such as HACCP, GAP, GMP certification, etc.

\subsubsection{Market Verification or Inspection System}

Market validation refers to the facilities of agricultural products cold chain logistics management main body, practitioners and other conditions of service, and service quality certification that inspection with proof of agricultural products cold chain logistics business entities taking free into the city. Certification includes the government designated certification body certification service quality certificate and designated inspection agency issued by the inspection report, etc. Verification of actuator can is agricultural products cold chain logistics market management department. It also can by the government instructing the market main body of exercising the power of the validation. In no entity or the market intermediary trading platform, service buyer reserves the right to ask for the proof. Otherwise buyer in the use of the service will assume direct responsibility. Into the city inspection and testing, it is not related to the production of agricultural products cold chain logistics operators, in the upcoming city services, before receiving a sample testing, testing qualified and entering the market services. There are three ways to detect the behavior of the main body: the inspection agency of the government department, the inspection agency of the market, and the inspection agency. The market body can not be allowed to enter the market service without examination of the qualification of inspection.

\subsection{Service Link}

Link service is an important part of the market access system. The link is mainly to solve the problem of asymmetric information service, which was followed by fake security shoddy service problem. Again, it is to prevent service process to produce secondary pollution problems. Effective monitoring of service quality safety market access is by the identification information and market sampling method.

\subsubsection{Identification Information System}

The main reason that causes the phenomenon of "inferior service quality service" is the information asymmetry 
problem, which must be included in the market access regulation. Article twenty-eighth: agricultural products production enterprise, farmer specialized cooperative organization, and engaged in the acquisition of agricultural products units or individual sales of agricultural products, in accordance with the provisions of the packaging or additional identification, must be approved by the packaging or additional identification can be sold. The packages or marks shall be in accordance with the law on agricultural product quality safety provisions marked product name, place of origin, producer, production date, shelf life, product quality and grade. The packages or marks should also be on the logistics process information labels such as logistics packaging materials, agent service, transportation equipment information, storage warehouse information.

\subsubsection{Market Inspection System}

The government regulation should take the market inspection system mainly through the verification of the service operation subject and the examination after entering the market. It mainly includes three aspects, namely, the verification service sampling, identification information inspection, etc. Verification service sampling means checking the effectiveness and accuracy of certification body and inspection agency certification or testing, inspection and supervision of the certification body and inspection agency behavior. Identification information inspection is mainly based on the identification information system to verify the accuracy of identification.

\subsection{Service Delisting Link}

The government should take measures to deal with the non-qualified service, which is not qualified for the examination of the market or the market.

\subsubsection{Service Exit System}

From the view of the form of withdrawal, the main points are forced to withdraw from the agreement. Compulsory withdrawal is the non qualified service to the inspection. The government or the market organization should be ordered to stop the service in the shortest time. And the main body of the service operation is not forced to withdraw from the market. Agreement to withdraw is from the service operators to find out of the non qualified service, the initiative to recover their own services, and to reach an agreement with the market organizers, compensation for the loss of related parties. Implementation of the "agreement to withdraw" is the production operator's reputation.

\subsubsection{Service Traceability System}

In the Chinese Agricultural Products Cold Chain Logistics Service process, the product supply chain is more complex. Product information is difficult to pass to the terminal market. If quality security incident occurs, or non qualified service is found, the actuator - the executive body — can only deal with the agricultural products and business operators involved in the inspection of the services. But other products on the market are still in sales, so the risk is great. To this end, we must establish a fast, unified and effective product traceability system. The system mainly includes the production record, information transmission, information carrier and product information platform. Service record is the record of the primary agricultural products cold chain logistics service providers and personnel, etc., which may affect the quality safety of agricultural products, such as the use of time, frequency, quantity and interval. It is a process of information and records of the cold chain logistics service provider. Through the establishment of traceability system, it can be easy for the government to implement the supervision and to facilitate the consumers to query service information, and to enhance consumer confidence, so as to improve the responsibility consciousness of service operator.

\section{Acknowledgements}

The fund project, the National Social Science Fund "The research of fresh agricultural products cold chain logistics management system for the needs of the city" (11BJY111).

\section{References}

[1] Wang, Y. (2004) The National Food Quality Safety Market, Guide. China Metrology Press, Beijing. 
[2] Mohan, R.C., Malliyala, S., Naresh, Y., Raghunandan, H.V. and Jinadatharaya, H. (2012) Good Cold Chain Management Practices. Journal of Pharmacy Research, 10, 5043-5047.

[3] Feng, Z.Z. and Chen, S. (2008) Analysis of the Content and Phase Development of China's Agricultural Product Quality Safety Market Access. System Sciences and Comprehensive Studies in Agriculture, 24.

[4] Liu, H.Y. (2007) The Problems and Countermeasures of Market Access in the Food Circulation Market. Commercial Economy, 27, 13-14.

[5] Zhang, M. (2010) Supply Chain Organization Model of Agricultural Products and Agricultural Products Quality Safety. Rural Economy, 8, 101-105.

[6] Xu, J.L. and Zhang, M.Y. (2011) Research on the Coordination Mechanism of Agricultural Products Supply Chain. Management Modernization, 2, 44-46. 